\title{
PENGEMBANGAN LKS IPA SMP KELAS VII BERBASIS PENDEKATAN SAINTIFIK UNTUK MELATIHKAN KETERAMPILAN PROSES IPA SISWA
}

\author{
Rohmatus Syafi'ah ${ }^{*}$, Alik Mustafidal Laili
}

\author{
Universitas Bhinneka PGRI ${ }^{1,2}$ \\ *corresponding Author: syafiahzainul@gmail.com
}

DOI: 10.24929/lensa.v10i2.115

\begin{abstract}
ABSTRAK
Saat ini pendidikan di Indonesia menerapkan Kurikulum 2013. Penilaian autentik dan pendekatan saintifik merupakan pendekatan yang digunakan di Kurikulum 2013. Pendekatan saintifik sesuai dengan karakteristik pembelajaran IPA. Proses pembelajaran IPA dengan menerapkan pendekatan saintifik yang menggunakan metode ilmiah mampu mengarahkan siswa dalam membandingkan hasil penafsiran siswa dengan teori yang ada melalui kegiatan eksperimen. Proses pembelajaran yang baik dan sesuai dengan harapan tentunya juga memerlukan dukungan sumber belajar yang terarah salah satunya adalah Lembar Kerja Siswa (LKS). Tujuan dalam penelitian ini adalah untuk menghasilkan LKS Berbasis Pendekatan Saintifik pada pelajaran IPA SMP untuk Melatihkan Keterampilan Proses Siswa yang disusun berdasarkan model pengembangan4-D (Define ,Design, Develop, and Disseminate). Hasil dari penelitian ini adalah LKS berbasis Pendekatan Saintifik yang telah dikembangkan mampu melatihkan keterampilan proses IPA siswa. Rata-rata persentase dari kelima aspek keterampilan proses IPA antara $72 \%$ sampai $96 \%$ termasuk dalam kategori baik dan sangat baik.
\end{abstract}

Kata Kunci : IPA; Keterampilan Proses IPA; LKS; Pendekatan Saintifik; 4-D

\section{ABSTRACT}

Currently education in Indonesia applies the 2013 curriculum. Authentic assessment and the scientific approach is the approach used in the 2013 curriculum. The scientific approach is in accordance with the characteristics of science learning. The scientific approach fits perfectly with the characteristics of science learning. The science learning process by applying a scientific approach that uses the scientific method is able to direct students in comparing the results of students' interpretations with existing theories through experimental activities. A good learning process and in accordance with expectations, of course, also requires the support of directed learning resources, one of which is the Student Activity Sheet (LKS). The purpose of this study was to produce a Science Approach-Based Middle School Science Worksheet for Practicing Student's Process Skills which were arranged based on the 4-D development model (Define, Design, Develop, and Disseminate). The result of this research is a scientific approach based worksheets that have been developed to be able to train students' science process skills. The average percentage of the five aspects of science process skills between $72 \%$ and $96 \%$ is in the good and very good categories.

Keywords: Science; Science Process Skills; LKS; Scientific approach; 4-D

\section{PENDAHULUAN}

Pendekatan saintifik adalah pendekatan pembelajaran yang dianjurkan untuk diterapkan dalam kurikulum 2013. Permendikbud No. 103 Tahun 2014 menyebutkan bahwa pembelajaran dengan pendekatan saintifik terdiri atas lima langkah kegiatan belajar yaitu mengamati, menanya, mengumpulkan informasi/mencoba, menalar atau mengasosiasi, mengomunikasikan yang dapat dilanjutkan dengan mencipta (Kemendikbud, 2014). Ke 5 Langkah pendekatan saintifik tersebut terintegrasi pada pendekatan keterampilan proses (Kementerian Pendidikan dan Kebudayaan Republik 
Indonesia, 2015). Tahapan-tahapan pendekatan saintifik dalam pembelajaran dapat digunakan sebagai sarana dalam mengembangkan pengetahuan, sikap, dan keterampilan peserta didik(Rohmawati, 2018).

Salah satu pendekatan pembelajaran ilmiah yang sangat cocok dengan karakteristik pembelajaran IPA adalah Pendekatan saintifik. Peserta didik dapat memahami berbagai materi dalam pembelajaran IPA melalui pendekatan saitifik dan menanamkan pada peserta didik bahwa informasi atau pengetahuan tidak hanya menggantungkan pada apa yang diberikan guru di kelas, tetapi juga dapat berasal darimana saja dan kapan saja (Fadhilaturrahmi, 2017). Dalam perkembangan dan pengembangan ranah pengetahuan, keterampilan, dan sikap peserta didik, pendekatan saintifik merupakan titian emas untuk ranah tersebut. (Dr. Rusman, 2017).

Pendekatan saintifik dianjurkan untuk diterapkan dalam Kurikulum 2013 untuk semua jenjang pendidikan dalah satunya adalah jenjang SMP. Tujuan diterapkannya pendekatan saintifik adalah agar peserta didik secara ilmiah mampu mengetahui, memahami, dan mempraktikkan apa yang sedang dipelajari. Oleh karena itu, peserta didik diajari keterampilan untuk mencari tahu dengan memanfaatkan berbagai macam sumber belajar, mengamati, menanya, mencoba, mengolah, menyajikan, menyimpulkan, dan mencipta untuk semua mata pelajaran (Pendekatan-Pendekatan Ilmiah dalam Pembelajaran, 2013). Hal ini sesuai dengan pendapat (Sufairoh, 2016) yang menyatakan bahwa pendekatan saintifik mengacu pada langkah kerja ilmiah.

Penekanan penerapan keterampilan proses IPA seyogyanya ada dalam proses pembelajaran IPA. Dalam belajar IPA, peserta didik seharusnya mampu bertindak seperti ilmuan yaitu melakukan penyelidikan ilmiah dengan menerapkan serangkaian keterampilan proses IPA. Keterampilan proses terdiri atas keterampilan proses terpadu dan keterampilan proses dasar (Depdikbud, 2014).Pengembangan keterampilan proses dilakukan melalui pengalaman langsung dalam proses pembelajaran. Penghayatan terhadap proses kegiatan yang dilakukan akan lebih mudah dilakukan melalui pengalaman langsung sehingga keterampilan proses IPA sangatlah penting untuk dikuasai. Seseorang dikatakan memiliki keterampilan proses IPA jika memiliki kemampuan dalam menerapkan metode ilmiah untuk memecahkan masalah dalam kehidupan sehari-hari, menemukan ilmu pengetahuan dan mengembangkan sains dikatakan (Lestari \& Diana, 2018). Melalui keterampilan proses IPA, siswa dapat lebih aktif dalam mengamati, mengelompokkan, menafsirkan, merencanakan percobaan atau penelitian, dan berkomunikasi (Prasasti, 2017). Selain harus dikuasai oleh siswa, keterampilan proses IPA juga penting untuh dipahami oleh guru khususnya guru mata pelajaran IPA(Subekti \& Ariswan, 2016).

Seseorang yang menguasai konsep keterampilan proses IPA, orang tersebut akan mudah dalam memecahkan masalah dan melakukan penelitian, karena kemampuan dalam memecahkan masalah dan penelitian merupakan hasil belajar yang paling tinggi yang harus dipelajari siswa (Ibrahim, 2010). Pengarahan untuk membandingkan hasil tafsiran dengan teori yang ada melalui eksperimen dengan metode ilmiah dapat diterapkan melalui pendekatan saintifik dalam pembelajatan IPA khususnya pada kegiata praktikum.Kegiatan praktikum memberikan pengalaman belajar langsung bagi siswa. Kegaiatan ini, tentunya akan berjalan sesuai dengan harapan jika ada dukungan dari sumber belajar yang sesuai dan terarah. Menurut (Azhar, 2008), Lembar Kerja Siswa (LKS) merupakan sumber belajar yang menjadikan proses pembelajaran lebih terarah.

Lembar Kerja Siswa (LKS) digunakan untuk membantu siswa memahami konsep materi baik yang dilaksanakan secara eksperimen maupun non eksperimen. Secara umum LKS memuat mata pelajaran, judul kegiatan, semester, kompetensi dasar, petunjuk belajar, indikator, keterangan pendukung, langkah kerja, dan tugas yang harus dilakukan (Daryanto, 2014). Hal tersebut di atas bertolak belakang dengan fakta yg ada di lapangan saat ini dimana LKS yang digunakan di sekolah umumnya hanya berisi tentang soal-soal latihan beruapa pertanyaan-pertanyaan atau rangkuman materi. LKS yang demikian tentunya tidak dapatmelatih keterampilan proses IPA melainkan hanya focus pada bias atau tidak bias dalam menjawab soal 
saja. Padahal, LKS yang seharusnya beredar adalah LKS yang mampu melatihkan keterampilan proses IPA yaitu LKS berbasis pendekatan saintifik.

Pengertian dari LKS berbasis pendekatan saintifik itu sendiri adalah LKS yang di dalamnya memuat pedoman bagi siswa dalam proses pembelajaran secara sistematis dan terorganisi dan berisi tahapan-tahapan metode ilmiah atau saintifik yang meliputi kegiatan pengamatan, eksperimen, pengumpulan data, analisis data, penarikan kesimpulan, dan mengkomunikasikan hasil pengamatan atau eksperimen yang mampu mengoptimalkan pengetahuan, keterampilan proses IPA, serta sikap ilmiah peserta didik ("Pengemb. LKS IPA Berbas. Sci. Approach Untuk Mengoptimalkan Learn. Outcome Siswa MTs Kelas VII," 2015). Pelatihan dan peningkatan kemampuan kemampuan berfikir peserta didik dalam dapat dilakukan dengan cara menggunakan metode yang sesuai dalam pengembangan LKS. Salah satu metode yang sesuai untuk yang sesuai dalam mengembangkan LKS IPA adalah metode Keterampilan proses IPA. Pernyataan ini seirama dengan dengan (Anggraini et al., 2016)bahwa melatih peserta didik untuk mengamati, mengelompokkan, berhipotesis, menganalisis, menyimpulkan, dan mengkomunikasikan melalui LKS berbasis keterampilan proses IPA mampumeningkatkan cara berfikir peserta didik. Tujuan dari penelitian ini adalah menghasilkan LKS Berbasis Pendekatan Saintifik pada materi IPA SMP untuk Melatihkan Keterampilan Proses Siswa yang disusun berdasarkan model pengembangan 4-D.

\section{METODE}

Jenis penelitian ini adalah penelitian pengembangan dengan mengikuti tahapan pengembangan Model 4-D (Thiagarajandalam Ibrahim, 2002). Tahapan dalam pengembangan Model 4-D meliputi: Define (Pendefinisian), Design (Perancangan), Develop (Pengembangan), dan Disseminate (Penyebaran). Secara diagram alur penelitian pengembangan LKS IPA SMP Berbasis Pendekatan Saintifik digambarkan seperti Gambar 3.1.

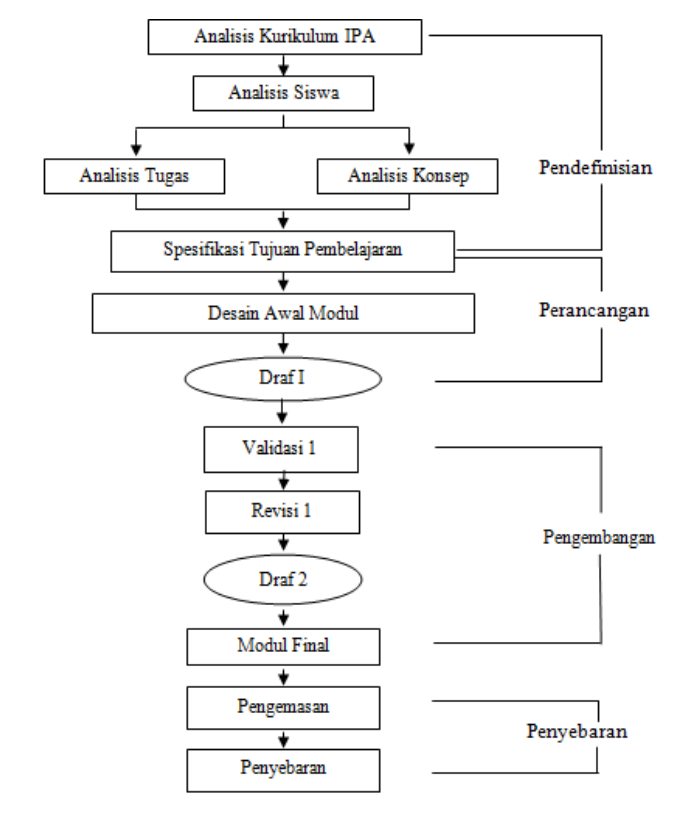

Gambar 3.1 Model Pengembangan Perangkat Pembelajaran Perangkat Model 4-D (Diadaptasi dari Ibrahim, 2002)

Lembar telaah dan validasi LKS, serta lembar angket respon siswa merupakan instrumen yang digunakan dalam penelitian pengembangan LKS ini, sedangkan metode yang digunakan untuk pengumpulan data adalah metode angket. 
Tabel 3.1 KriteriaPenilaian Validasi LKS

\begin{tabular}{cc}
\hline Skor Rata-rata & Kriteria \\
\hline $1,0 \leq X \leq 1,9$ & Tidak valid \\
\hline $2,0 \leq X \leq 2,9$ & Kurang valid \\
\hline $3,0 \leq X \leq 3,9$ & Cukup valid \\
\hline $4,0 \leq X \leq 5,0$ & Valid
\end{tabular}

(Sridana, 2007)

Analisis keterampilan proses IPA terhadap LKS diuraikan secara kualitatif deskriptif. Skala likert digunakan untuk mennganalisis hasil angket respons siswa terhadap LKS IPA berbasis pendekatan saintifik dianalisis. Angket respon siswa berisi pernyataan yang diisi dengan checklist. Jawaban dari pernyataan diberi skor untuk mempermudah dalam menganalisis. Skor respon siswa terhadap LKS ditunjukkan seperti pada Tabel 3.2.

Tabel 3.2 Skala Sikap Respon Siswa

\begin{tabular}{ccc}
\hline Sikap & Keterangan sikap & Skor \\
\hline SS & Sangat Setuju & 4 \\
\hline S & Setuju & 3 \\
\hline TS & Tidak Setuju & 2 \\
\hline STS & Sangat Tidak Setuju & 1 \\
\hline
\end{tabular}

(Suharsimi; , 2013)

\section{HASIL DAN PEMBAHASAN}

Pada penelitian ini, model pengembangan yang digunakan adalah model pengembangan 4-D (Four-D Models) tetapi hanya sampai pada tahap ke 3 yaitu tahap pengembangan (develop). Hasil penelitian yang diperoleh dari setiap tahap pengembangan dan analisis data dideskripsikan sebagai berikut : (1) LKS berbasis pendekatan saintifik khusus pada materi IPA SMP Kelas VII Semester Ganjil, (2) penilaian LKS oleh ahlimateri dan ahli desain pembelajaran. (3) responsiswa terhadap LKS yang telah dibuat, (4) keterampilan proses IPA siswa

LKS yang dikembangkandirancang dengan berbagai variasi gambar dan warna, menggunakanbahasa yang mudah dipahamisiswa, serta materi disajikan secara sistematis. Adapun tahapan dari pelaksanaan penelitian yang dilakukan adalah sebagai berikut:

\section{Tahap Pendefinisian (Define)}

Kegiatan yang dilaksanakan pada tahap ini adalah analisis siswa, analisis kurikulum, analisis tugas, analisis konsep, dan menetapkan capaian pembelajaran.

2. Tahap Perancangan (Design)

Menyusun produk berdasarkan hasil analisis kurikulum, analisis konsep, analisis siswa, analisis tugas, dan perumusan capaian pembelajaran, tersusunlah draf 1 berupa LKS berbasis pendekatan saintifik. Format dalam penyusunan LKS ini disesuaikan dengan karakteristik siswa dan disesuikan dengan pendekatan saintifik. Selain itu, peneliti juga membuat angket respon siswa dan soal tes keterampilan proses IPA.

\section{Tahap Pengembangan (Develop)}

LKS yang dikembangkan merupakan hasil draft 1 yang kemudian ditelaah dan direvisi. Adapun validatornya terdiri dari 4 orang yaitu validator ahli materi 2 orang ( 1 guru dan 1 dosen) dan 2 orang validator ahli media (1 guru dan 1 dosen). 
Tabel 3. Hasil Validasi Ahli Materi

\begin{tabular}{|c|c|c|c|c|c|}
\hline \multirow[t]{2}{*}{ No } & \multirow[t]{2}{*}{ Pernyataan } & \multicolumn{2}{|c|}{ Skor } & \multirow[t]{2}{*}{ Rata-rata } & \multirow[t]{2}{*}{ Kategori } \\
\hline & & V1 & V2 & & \\
\hline \multicolumn{6}{|c|}{ I.Aspek Petunjuk } \\
\hline 1. & Mencantumkan Kompetensi Dasar (KD) & 5 & 5 & 5 & Valid \\
\hline 2. & Mencantumkan judul kegiatan & 5 & 4 & 4,5 & Valid \\
\hline 3. & Mencantumkan tujuan kegiatan & 5 & 5 & 5 & Valid \\
\hline 4. & Materi pada LKS sesuai dengan KD & 4 & 4 & 4 & Valid \\
\hline 5. & $\begin{array}{l}\text { Petunjuk dalam LKS dinyatakan dengan } \\
\text { jelas }\end{array}$ & 4 & 4 & 4 & Valid \\
\hline \multicolumn{6}{|c|}{ II. Isi yang Disajikan } \\
\hline 1. & Penyajian materi pada LKS sistematis & 5 & 5 & 5 & Valid \\
\hline & $\begin{array}{l}\text { Tugas/ materi yang ada dalam LKS } \\
\text { esensial }\end{array}$ & 4 & 5 & 4,5 & Valid \\
\hline 3. & $\begin{array}{l}\text { Masalah yang dalam LKS sesuai dengan } \\
\text { tingkatkognitif siswa }\end{array}$ & 4 & 5 & 4,5 & Valid \\
\hline 4. & $\begin{array}{l}\text { Mencantumkan tujuan yang jelas dalam } \\
\text { setiap kegiatan }\end{array}$ & 5 & 5 & 5 & Valid \\
\hline & $\begin{array}{l}\text { Penyajian kegiatan dalam LKS dapat } \\
\text { menumbuhkanrasa ingin tahu siswa }\end{array}$ & 4 & 5 & 4,5 & Valid \\
\hline & $\begin{array}{l}\text { Kegiatan dalam LKS memotivasi siswa } \\
\text { untuk menggali informasi lebih lanjut }\end{array}$ & 4 & 5 & 4,5 & Valid \\
\hline 7. & Memuat pendekatan saintifik & 5 & 5 & 5 & Valid \\
\hline & $\begin{array}{l}\text { LKS dapat melatihkan keterampilan } \\
\text { proses IPA siswa }\end{array}$ & 5 & 5 & 5 & Valid \\
\hline 9. & Terdapat muatan nilai karakter & 5 & 5 & 5 & Valid \\
\hline & $\begin{array}{l}\text { Prosedur kerja jelas,tidak menimbulkan } \\
\text { makna ganda, dan mudah dimengerti }\end{array}$ & 5 & 4 & 4,5 & Valid \\
\hline & $\begin{array}{l}\text { Kesesuaian pertanyaan dengan materi } \\
\text { dan kegiatan }\end{array}$ & 4 & 5 & 4,5 & Valid \\
\hline 12. & Pertanyaan mendukung konsep & 4 & 5 & 4,5 & Valid \\
\hline \multicolumn{6}{|c|}{ III. Aspek Bahasa } \\
\hline & $\begin{array}{l}\text { Bahasa yang digunakan sesuai dengan } \\
\text { EYD }\end{array}$ & 4 & 5 & 4,5 & Valid \\
\hline & $\begin{array}{l}\text { Bahasa yang digunakan sesuai dengan } \\
\text { tingkat perkembangan kognitif siswa }\end{array}$ & 5 & 3 & 4 & Valid \\
\hline & $\begin{array}{l}\text { Kalimat yang digunakan jelas dan } \\
\text { mudah dimengerti }\end{array}$ & 5 & 4 & 4,5 & Valid \\
\hline 4. & Petunjuk atau arahan jelas & 5 & 3 & 4 & Valid \\
\hline & Kejelasan pertanyaan & 5 & 5 & 5 & Valid \\
\hline
\end{tabular}

\section{Keterangan :}
V1 $=$ Validator ahli materi 1
V2 = Validator ahli materi2

Rata-rata penilaian ahli materi terhadap LKS pada semua aspek 4,59 termasuk kategori valid. Artinya LKS yang dikembangkan layak digunakan, tetapi perlu diperbaiki sesuai dengan saran dari validator.

Tabel 4. Hasil Validasi Ahli Media

\begin{tabular}{|c|c|c|c|c|c|c|c|}
\hline \multirow[t]{2}{*}{ No } & \multirow{2}{*}{\multicolumn{3}{|c|}{ Pernyataan }} & \multicolumn{2}{|c|}{ Skor } & \multirow[t]{2}{*}{ Rata-rata } & \multirow[t]{2}{*}{ Kategori } \\
\hline & & & & V1 & V2 & & \\
\hline \multicolumn{8}{|c|}{ I.Aspek Komunikasi Media LKS } \\
\hline 1. & $\begin{array}{l}\text { Ide atau } \\
\text { kreatif }\end{array}$ & gagasan yang & dituangkan & 5 & 5 & 5 & Valid \\
\hline 2. & Visual (des & ain, warna LKS) & & 5 & 4 & 4,5 & Valid \\
\hline
\end{tabular}




\begin{tabular}{|c|c|c|c|c|c|}
\hline \multirow[t]{2}{*}{ No } & \multirow[t]{2}{*}{ Pernyataan } & \multicolumn{2}{|c|}{ Skor } & \multirow[t]{2}{*}{ Rata-rata } & \multirow[t]{2}{*}{ Kategori } \\
\hline & & V1 & $\mathbf{V 2}$ & & \\
\hline 3. & $\begin{array}{l}\text { Bentuk LKS yang digunakan dalam } \\
\text { peneliitian }\end{array}$ & 5 & 5 & 5 & Valid \\
\hline \multicolumn{6}{|c|}{ II. Aspek Desain Pembelajaran } \\
\hline 1. & Interaktivitas & 5 & 5 & 5 & Valid \\
\hline 2. & Pemberian motivasi belajar & 4 & 5 & 4,5 & Valid \\
\hline 3. & Penyajiannya menarik perhatian siswa & 4 & 5 & 4,5 & Valid \\
\hline 4. & $\begin{array}{l}\text { Guru dapat } \begin{array}{c}\text { dengan } \\
\text { menggunakan }\end{array} \text { mudah } \\
\text { pembelajaran }\end{array}$ & 5 & 5 & 5 & Valid \\
\hline 5. & 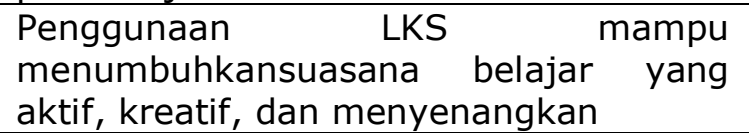 & 4 & 5 & 4,5 & Valid \\
\hline
\end{tabular}

\section{Aspek Lain}

\begin{tabular}{llcccc}
\hline 1. & LKS sesuai dengan sajian materi & 4 & 5 & 4,5 & Valid \\
\hline 2. & $\begin{array}{l}\text { Konsistensi penggunaan LKS dengan } \\
\text { materi sajian }\end{array}$ & 5 & 3 & 4 & Valid \\
\hline 3. & Petunjuk penggunaan LKS & 5 & 4 & 4,5 & Valid \\
\hline \multicolumn{2}{c}{ Rata- rata semua aspek } & & & $\mathbf{4 , 6 4}$ & Valid \\
\hline
\end{tabular}

\section{Keterangan :}

V1 = Validator ahli media 1

V2 = Validator ahli media 2

Rata-rata penilaian dari ahli media pada semua aspek sebesar 4,64 termasuk kategori valid. Artinya LKS yang dikembangkan adalah layak digunakan dalam pembelajaran, tetapi masih perlu diperbaiki sesuai dengan saran perbaikan dari validator. Hal ini sejalan dengan hasil penelitian (Rusdi, 2018) yaitu LKS berbasis pendekatan saintifik pada materi pembelajaran Biologi kelas VII SMP yang dikembangkan dengan model 4-D layak digunakan dalam pembelajaran.

Respon siswa penelitian ini dilihat dari tanggapan siswa setelah membaca dan melakukan kegiatan berdasarkan LKS yang telah dikembangkan yang diukur dengan angket. Tabel 5 di bawah ini adalah hasil analisis angket respon siswa terhadap LKS yang dikembangkan.

Tabel 5.Hasil Analisis Angket Respon Siswa

\begin{tabular}{clll}
\hline Kriteria & \multicolumn{1}{c}{ Indikator } & \multicolumn{1}{c}{ Interval (\%) } & \multicolumn{1}{c}{ Respon } \\
\hline \multirow{2}{*}{ Tanggapan } & Susunan LKS & $82 \%$ & Positif \\
\cline { 2 - 4 } & Kesesuaian & $80 \%$ & Positif \\
\hline \multirow{3}{*}{ Reaksi } & Atensi & $79 \%$ & Positif \\
\cline { 2 - 4 } & Kepuasan & $78 \%$ & Positif \\
\cline { 2 - 4 } & Percaya Diri & $67 \%$ & Kurang Positif \\
\hline Respon Siswa & & $77,2 \%$ & Positif \\
\hline
\end{tabular}

Tanggapan siswa terhadap susunan LKS yang telah dikembangkan berada dalam interval $82 \%$ masuk dalam kategori tinggi. Respon siswa positif terhadap sajian materi, gambar, dan pertanyaan-pertanyaan pada LKS. $90 \%$ siswa menyatakan tidak kecewa terhadap penyajian LKS yang dikembangkan ini karena tidak ada gambar yang mengganggu. Selain itu, penyajian LKS juga menggunakan bahasa dan kalimat yang mudah dimengerti.

Indikator kesesuaian dari LKS yang telah dikembangkan dilihat dari konsistensi capaian belajar siswa, kesesuaian isi LKS dengan cara belajar siswa, dan keseuaian dengan pengalaman belajar. Rata-rata tanggapan siswa terhadap kesesuaian LKS yang dikembangkan sebesar $80 \%$ dengan kategori respon positif. Artinya materi yang ditampilkan dalam LKS sesuai dengan pengalaman belajar, sesuai dengan kebutuhan belajar siswa, dan bermanfaat. 
Reaksi terhadap LKS diukur dari indikator atensi, percaya diri, dan kepuasan. Sebesar $79 \%$ siswa tertarik terhadap LKS ini, artinya sebagian besar siswa senang dengan tampilan dalam LKS. Hal ini sejalan dengan pendapat Berlyne dan Kopp (Risandi, n.d.) yaitu betapa pentingnya menggabungkan berbagai taktik (gambar atau peristiwa yang menarik) untuk memperoleh perhatian siswa.

Sebesar $78 \%$ kepuasan siswa terhadap LKS ini tergolong respon positif. Artinya LKS ini mampu membuat siswa lebih semangat dan termotivasi dalam pengalaman belajar mereka. Siswa merasakan suasana belajar yang berbeda dimana siswa merasa senang sehingga timbul keinginan untuk lebih giat lagi dalam mempelajari materi. Siswa menganggap pembelajaran dengan menggunakan LKS ini merupakan pengalaman belajar yang menarik dan pengalaman belajar yang baru.

Setelah melihat dan menggunakan LKS ini, rata-rata persentase rasa percaya diri siswa sebesar $67 \%$ dengan kategori respon kurang positif. Sebagian besar siswa mengungkapkan bahwa jika hanya satu kali saja melihat sajian materi di LKS, mereka merasa belum yakin dan kurang percaya diri untuk menjawab pertanyaan-pertanyaan yang ada di LKS. Seharusnya guru tidak hanya menggunakan LKS dalam satu kali pertemuan saat penelitian saja namun pada pertemuan-pertemuan berikutnya sehingga rasa percaya diri siswa dalam menyelesaikan pertanyaan di LKS dapat meningkat.

Tabel 6. Rekapitulasi Tiap Aspek Keterampilan proses IPA Aspek Keterampilan proses IPA

\begin{tabular}{ccccccccc} 
No & $\begin{array}{c}\text { Nama } \\
\text { Siswa }\end{array}$ & $\begin{array}{c}\text { Mengam Mengkla Mengan } \\
\text { ati } \\
\text { sifikasi }\end{array}$ & & & $\begin{array}{c}\text { Menyim } \\
\text { alisis }\end{array}$ & $\begin{array}{c}\text { Mengkom } \\
\text { unikasika } \\
\text { n }\end{array}$ & $\begin{array}{c}\text { Skor } \\
\text { yang } \\
\text { diperol } \\
\text { eh }\end{array}$ & $\begin{array}{c}\text { Perse } \\
\text { ntase }\end{array}$ \\
\hline 1. & $\mathrm{~A}$ & 5 & 3 & 4 & 4 & 5 & 21 & $84 \%$ \\
\hline 2. & $\mathrm{~B}$ & 5 & 4 & 3 & 4 & 4 & 20 & $80 \%$ \\
\hline 3. & $\mathrm{C}$ & 5 & 5 & 4 & 5 & 4 & 23 & $92 \%$ \\
\hline 4. & $\mathrm{D}$ & 5 & 5 & 4 & 5 & 4 & 23 & $92 \%$ \\
\hline 5. & $\mathrm{E}$ & 5 & 5 & 4 & 5 & 5 & 24 & $96 \%$ \\
\hline 6. & $\mathrm{~F}$ & 5 & 4 & 3 & 3 & 4 & 19 & $76 \%$ \\
\hline 7. & $\mathrm{G}$ & 5 & 3 & 4 & 3 & 3 & 18 & $72 \%$ \\
\hline 8. & $\mathrm{H}$ & 5 & 4 & 4 & 5 & 4 & 22 & $88 \%$ \\
\hline 9. & $\mathrm{I}$ & 5 & 5 & 4 & 5 & 5 & 24 & $96 \%$ \\
\hline 10 & $\mathrm{~J}$ & 5 & 5 & 5 & 4 & 5 & 19 & $76 \%$ \\
\hline
\end{tabular}

Berdasarkan hasil rekapitulasi tiap aspek keterampilan proses IPA dapat diketahui bahwa aspek keterampilan proses IPA yang paling baik dan kesepuluh siswa memperoleh skor maksimal yaitu pada aspek mengamati. Hal ini terlihat dari antusias dan rasa penasaran siswa terhadap apa yang mereka amati pada saat proses pembelajaran berlangsung dengan menggunakan LKS berbasis pendekatan saintifik tersebut. Sementara pada keterampilan proses IPA menganalisis terlihat bahwa skor yang diperoleh oleh kesepuluh siswa hanya ada satu siswa yang memperoleh skor maksimal yaitu 5. Hal ini dikarenakan siswa kurang mampu mengaitkan apa yang mereka temukan dalam pengamatan dengan teori atau literasi yang sudah mereka baca. Secara keseluruhan rata-rata persentase dari kelima aspek keterampilan proses IPA tersebut di atas berada dalam kategori baik (72\%) dan sangat baik (96\%).

Skor rata- rata hasil validasi LKS sebesar 4,62 dengan kriteria sangat baik. Artinya dalam penyusunan LKS, peneliti mempertimbangkan tingkat kognitif siswa. Hal ini sesuai dengan teori perkembangan kognitif Piaget yang menyatakan bahwa anak usia SMP berada pada tahap operasional formal dimana mampu membentuk operasi operasi kompleks melalui operasi-operasi konkret dan mampu menyelesaikan permasalahan dengan menggunakan eksperimen (Woolfolk, 2009). LKS yang telah dikembangkan sesuai dengan teori ini karena siswa diberikan perhatian dan bagian tentang proses berpikir, lebih dari sekedar hasil melalui kegiatan pengamatan/ eksperimen dan diskusi kelompok. 
Kegiatan eksperimen dalam LKS yang dikembangkan menjadikan siswa aktif dalam menggali informasi lebih lanjut dalam proses pembelajaran yan sesuai dengan teori konstruktivis dimana siswa harus menjadikan informasi itu miliknya sendiri secara aktif dengan membangun sendiri pengetahuan atau konsep berdasarkan pengetahuan dan pengalaman yang dimiliki (Arends, 2008). Selain itu, LKS yang telah dikembangkan juga telah melatihkan langkah- langkah pendekatan saintifik sesuai tuntutan kurikulum 2013 dengan skor validasi sebesar 5 dengan kriteria sangat baik. Langkah- langkah pendekatan saintifik di dalam LKS misalnya seperti: mengamati (siswa diminta untuk memahami suatu fenomena yang disajikan di awal LKS); menanya(siswa diminta untuk merumuskan pertanyaan terkait fenomena yang telah disajikan); mengumpulkan informasi/eksperimen (siswa diminta untuk mengamati dan menuliskan data hasil pengamatan); mengasosiasi (siswa diminta untuk menganalisis data hasil pengamatan); mengkomunikasikan (siswa diminta untuk mempresentasikan data hasil pengamatan di depan kelas).

Selain hal tersebut di atas, LKS yang dikembangkan berisi serangkaian kegiatan mendasar dimana dengan adanya kegiatan tersebut diharapkan mampu memaksimalkan pemahaman siswa sesuai dengan indikator pencapaian hasil belajar yang harus ditempuh, memuat langkah-langkah pendekatan saintifik seperti tuntutan pembelajaran dalam kurikulum 2013, memberi kesempatan kepada siswa untuk berlatih menyusun jawaban sementara, membuktikan kebenaran jawaban sementara dengan melakukan eksperimen/ pengamatan, dan menarik kesimpulan berdasarkan data yang diperoleh.

Penelitian relevan dilakukan oleh (Wardani \& Widiana, 2018) menyatakan bahwa LKS saintifik berbasis keterampilan berpikir kritis yang dikembangkan memenuhi kriteria validitas dan keefektifan. Hasil dari penelitian lain yang senada yaitu LKS berbasis pendekatan saintifik yang dikembangkan valid dan praktis untuk digunakan dalam pembelajaran (Fitriana et al., 2016).

\section{KESIMPULAN}

Berdasarkan hasil penelitian ini rata-rata persentase dari kelima aspek keterampilan proses IPA, berada dalam kategori baik dan sangat baik dengan perolehan persentase total antara $72 \%$ sampai $96 \%$. Artinya LKS yang telah dikembangkan mampu melatihkan keterampilan proses IPA siswa.

\section{SARAN}

Pada penelitian selanjutnya bisa dikembangkan LKS berbasis pendekatan saintifik untuk melatihkan keterampilan proses pada kelas yang berbeda dengan menambahkan poin-poin keterampailan proses yang lain. Untuk LKS bisa dibuat kreasi warna-warna yg menarik untuk menumbuhkan motivasi siswa.

\section{DAFTAR PUSTAKA}

Anggraini, R., Wahyuni, S., \& Lesmono, A. (2016). PENGEMBANGAN LEMBAR KERJA SISWA (LKS) BERBASIS KETERAMPILAN PROSES DI SMAN 4 JEMBER. JURNAL PEMBELAJARAN FISIKA.

Arends, R. . (2008). Learning to teach. Pustaka Pelajar.

Azhar, A. (2008). Media pembelajaran; Edisi revisi. In Repositori Riset Kesehatan Nasional.

Daryanto. (2014). Pengembangan Perangkat Pembelajaran. Gava Media.

Depdikbud. (2014). PERMENDIKBUD No.58 Th. 2014 tentang Kurikulum 2013 Sekolah Menengah 
http://staff.unila.ac.id/ngadimunhd/files/2012/03/Permen-58-ttgKurikulumSMP.doc.

Dr. Rusman. (2017). Belajar \& Pembelajaran: Berorientasi Standar Proses Pendidikan. In PT Kharisma Putra Utama.

Fadhilaturrahmi, F. (2017). PENERAPAN PENDEKATAN SAINTIFIK UNTUK MENINGKATKAN KEMAMPUAN KOMUNIKASI MATEMATIK PESERTA DIDIK di SEKOLAH DASAR. EduHumaniora | Jurnal Pendidikan Dasar Kampus Cibiru. https://doi.org/10.17509/eh.v9i2.7078

Fitriana, D., Yusuf, M., \& Susanti, E. (2016). PENGEMBANGAN LEMBAR KERJA SISWA MENGGUNAKAN PENDEKATAN SAINTIFIK UNTUK MELIHAT BERPIKIR KRITIS SISWA MATERI PERBANDINGAN. Jurnal Pendidikan Matematika. https://doi.org/10.22342/jpm.10.2.3629.23-38

Ibrahim, M. (2010). Dasar-Dasar Proses Belajar Mengajar. Universitas Negeri Surabaya University Press.

Kemendikbud. (2014). Permendikbud Nomor 103 Tahun 2014 Tentang Pembelajaran Pada Pendidikan Dasar dan Pendidikan Menengah. Pedoman Evaluasi Kurikulum.

Kementerian Pendidikan dan Kebudayaan» Republik Indonesia. (2015). Target Kemendikbud Dalam Pengembangan Pendidikan dan Kebudayaan Tahun 2017. Kementerian Pendidikan Dan Kebudayaan.

Lestari, M. Y., \& Diana, N. (2018). Keterampilan proses sains (KPS) pada pelaksanaan praktikum Fisika Dasar I. Indonesian Journal of Science and Mathematics Education.

Pengembangan LKS IPA Berbasis Scientific Approach untuk Mengoptimalkan Learning Outcome Siswa MTs Kelas VII. (2015). Pengembangan LKS IPA Berbasis Scientific Approach Untuk Mengoptimalkan Learning Outcome Siswa MTs Kelas VII. https://doi.org/10.21831/jpms.v6i2.10949

Risandi, R. (n.d.). Respon Siswa SMA Negeri Pontianak Terhadap Lembar Kerja Siswa Berbasis Multimedia Sub Materi Invertebrata. Jurnal Pendidikan Dan Pembelajaran Untan. https://www.neliti.com/publications/217249/respon-siswasma-negeri-pontianak-terhadap-lembar-kerja-siswa-berbasis-multimedi\%0A\%0A

Rohmawati, S. S. S. (2018). PENERAPAN PENDEKATAN SAINTIFIK PADA MATA PELAJARAN IPA DI MTS PUTRI NURUL MASYITHOH LUMAJANG. Jurnal Kajian Teknologi Pendidikan, 1. http://journal2.um.ac.id/index.php/jktp/article/view/4543

Sridana, N. (2007). Pengembangan Model Pelatihan untuk PenyusunanRincian Materi Pengalaman Belajar Matematika bagi Guru Kelas VII melalui Penerapan Kriteria Pemilihan yang Berbasis Konstruktivisme. Disertasi Tidak Dipublikasikan.

Subekti, Y., \& Ariswan, A. (2016). Pembelajaran fisika dengan metode eksperimen untuk meningkatkan hasil belajar kognitif dan keterampilan proses sains. Jurnal Inovasi Pendidikan IPA. https://doi.org/10.21831/jipi.v2i2.6278

Pendekatan-Pendekatan Ilmiah dalam Pembelajaran, (2013).

Sufairoh. (2016). Pendekatan Saintifik \& Model Pembelajaran K-13. Bahastra. 
Suharsimi; , A. (2013). Dasar-Dasar Evaluasi Pendidikan. In Jakarta: Bumi Aksara.

Wardani \& Widiana. (2018). Pengembangan Lembar Kerja Siswa (LKS) Saintifik Berbasis Keterampilan Berpikir Kritis untuk Siswa Kelas V SD/MI di Kabupaten JombangNo Title. Jurnal Bidang Pendidikan Dasar (JBPD),2. http:ejournal.unikama.ac.id/index.php/JBPD

Woolfolk, A. (2009). Educational Psychology: Active Learning Edition. Pustaka Pelajar. 